\title{
A educación galega hoxe: consideracións históricas, realidades e perspectivas
}

Hoxe, cando xa corre -ou galopa — o ano 2000, non é posible falar dun sistema educativo galego sen pensar en Europa. Si, en cambio, poderíase falar dun sistema educativo galego, pensando nunha estrutura diferente do Estado, en España. Naturalmente, estamos partindo do suposto de que o sistema educativo é un sistema de Estado, por tanto, parte inseparable e irrenunciable da estrutura estatal.

A escola como institución, segue a ser un dos máis importantes aparatos ideolóxicos do Estado, como, de maneira tan clarividente, dixera un día o filósofo francés Louis Althusser, no memorable artigo titulado $O$ aparato ideolóxico escolar do Estado como aparato dominante, que, como se sabe, revolucionou a metodoloxía e a orientación xeral da investigación sociolóxico-educativa e tamén, en boa medida, a historia da educación, principalmente en todo o que se relaciona coa "historia dos sistemas educativos".

En realidade, xa tiña sido así desde os tempos lonxanos e case míticos da Grecia clásica. Para Platón, era inconcibible un Estado ben construído sen un poderoso sistema educativo ó seu servizo. Máis aínda: o sistema educativo era a mellor garantía da perdurabilidade do Estado. E tamén a mellor garantía do bo goberno e da máis coidada selección dos seus gardiáns, como el dicía. (Hoxe, nunha linguaxe moito máis burocratizada, falaríamos máis ben de funcionarios do Estado). Estábase a referir Platón ó papel cohesionador e unificador da educación na Cidade-Estado, á súa función de control dos ideólogos e dos gardiáns armados (a célebre trimembración platónica: sabedoría para os filósofos —os políticos das Cidades-, forza para os guerreiros e prudencia para os traballadores) e, en xeral, ó rol insubstituíble da educación na estrutura estatal. Non pode haber Estado sen Educación nin Educación sen Estado, dicía Platón.

Como se ve, estamos a asistir ás orixes teóricas da educación en tanto que sistema ó servizo do Estado - institución suprema da sociedade-. Por iso, moitos anos despois, xa en pleno século XVIII, Jean-Jacques Rousseau, na audaz e revolucionaria síntese políticopedagóxica que leva a cabo no Emilio e no Contrato Social, afirma con resolución que $A$ República - unha das obras máis importantes de Platón- non é unha obra de política -como pensan os que len os libros só polos seus títulos-, senón "o máis fermoso tratado de educación que se teña escrito nunca".

Non hai dúbida de que foi Platón o fundador, en Atenas, da teoría educativa, en tanto que reflexión profunda sobre o papel da educación na sociedade e no individuo — tal e como sinala na súa famosa Antoloxía o pedagogo institucionista Lorenzo Luzuriaga-. A través da súa filosofía da polis, Platón descobre a importancia da educación para o 
bo funcionamento do Estado. E na República amosa un modelo de inserción do sistema educativo na estrutura estatal. Será el o primeiro en entender o carácter reprodutor da educación e o primeiro en concluír que a educación actúa como elemento perpetuador de certos valores e intereses sociais.

A súa tan citada trimembración (sabedoría para os filósofos e gobernantes, fortaleza para os guerreiros e prudencia para os traballadores) recóllese na metáfora dos cidadáns de ouro, prata e bronce. Metáfora que conlevaba case sempre unha mobilidade social descendente, pero case nunca ascendente e que se inspiraba no sistema social de castas do antigo Exipto. Os cidadáns de ouro que non saiban estar a altura das esixencias do Estado, poderán seren "degradados" a prata ou bronce, pero non ó revés... Porque se hai bronce ou prata onde debe haber ouro, periga a seguridade do Estado... Como poden ver, a lección sociolóxica actual da teoría platónica da educación e do Estado é ben fácil de sacar.

Nunha vertente moito máis práctica, Aristóteles vai profundizar na sistematización teórica do seu mestre. Pensa tamén que a educación é unha tarefa esencial do Estado, aínda que -máis pragmático el— buscará un acomodo do sistema educativo á forma de goberno do Estado. Na Política atopamos páxinas modélicas sobre a función da educación no Estado así como consideracións profundísimas sobre a pegada da educación no individuo. Aristóteles distingue por exemplo entre educación, como política educativa do Estado, e habituación, en tanto que inculcación de normas e modelación interna da persoa. Isto é, distingue entre educación como política educativa (educación da polis) e educación como formación individual.

A denominación mesma dos respectivos centros de ensino dos dous grandes filósofos gregos - a Academia de Platón e o Liceo de Aristóteles- e o "éxito" pedagóxico e institucional que terían ó longo da Historia, dannos unha pista sobre a sólida base teóricoeducativa legada polos dous grandes clásicos da cultura helénica.

As consideracións aristotélicas sobre as clases de educación, en función das clases sociais e da división social do traballo, seguen a ser un referente ó que se remitirán os autores do Renacemento, os ilustrados do século XVIII ou os pensadores socialistas do XIX e o XX. As "distincións" entre "os traballos dos homes libres e os servís" marcaron un fito aínda non superado na análise sociolóxica. As "cuestións de clase" seguen a ter idéntica consideración, aínda que tamizadas -e matizadas- polas conquistas da revolución científico-técnica nas súas distintas fases e pola superación dalgunhas das características que separaban o traballo manual do traballo intelectual.

\section{Unha aproximación crítica}

En 1978, aparecía en Galicia un libro que tería un destino singular... Galicia. Realidade económica e conflicto social foi unha publicación auspiciada polo Banco de Bilbao e coordinada por José Antonio Durán Iglesias. Nada máis saír do prelo, foi "secuestrada" polo propio Servizo de Estudos do Banco. Libro editado en galego e castelán, resulta hoxe practicamente inencontrable; circula só un reducidísimo número de exemplares. Investi- 
gación aberta —como di Durán na Presentación—, acadou certa sona no seu tempo por algunhas "audacias" críticas. Publícase no período inicial da chamada "transición democrática" e abrangue bo número de aspectos socioeconómicos, laborais, artísticos, culturais e educativos sobre a realidade galega daqueles anos.

No traballo encol da educación, acometido por Antón Costa e por min mesmo, na obra colectiva citada, establécese unha primeira aproximación crítica á "problemática educacional" galega dos anos 70. E vese ben o subdesenvolvemento educativo e cultural do noso país. Galicia estaba daquela por debaixo da media estatal en case todos os indicadores escolares importantes. Por suposto, en todos os niveis — preescolar (como se dicía entón), primaria, secundaria, profesional e superior-. Chamaba a atención a pobreza extrema á hora dunha análise cualitativa; e non digamos xa se reparamos nas estatísticas. Por poñer un exemplo, 0 "preescolar" estaba daquela algo máis de 10 puntos por debaixo da media estatal.

Curiosamente, fora Galicia un banco de probas para a publicación do Libro Blanco (1969), no que se basearía a "Ley General de Educación" de 1970. Lei que vén ser, anos despois, un referente inescusable para entender o estado actual do sistema educativo español e as súas posibles reestruturacións futuras, sempre en estreita correlación co modelo de Estado que se pretenda. En calquera tipo de análise macroeducativa, sempre será unha constante a correlación entre sistema produtivo e sistema educativo, así como entre sistema educativo e sistema político. Isto é, de tal sistema socioeconómico, tal modelo educativo e con tal réxime político, tal tipo de educación —como, dalgunha forma, xa dera a entender o propio Aristóteles-. Por iso, falar de educación supón case sempre falar de economía e de política. (A non ser que esteamos a dilucidar simples cuestións técnicas, metodolóxicas ou estritamente didácticas, isto é, intraescolares). Do mesmo xeito, falar da educación con adxectivos, supón igualmente abordar cuestións socioeconómicas ou políticas. No caso do noso país, se cavilamos en termos de educación nacional-popular - como diría Gramsci- deberemos perfilar ese concepto sobre o fondo escuro, denso e constante do sistema social; ou referilo ó fondo máis cambiante, colorista e inmediato do sistema político.

¿Que significou verdadeiramente a "Ley General de Educación" de 1970, a chamada popularmente "Ley Villar" - recordando ó ministro que a asinou - no desenvolvemento pedagóxico-político español? Se houbese que propoñer datas concretas para un estudo cabal do sistema educativo franquista, o acoutamento cronolóxico primeiro sería 19381970. Desde o punto de vista político-pedagóxico, iso é o que dura o franquismo. Arrinca en Burgos, en plena guerra civil, coa famosa Lei da xefatura do Estado "golpista" de 20 de setembro de 1938 (a Lei do Bacharelato "dos sete anos", inspirada polo ministro monárquico Pedro Sáinz Rodríguez —o "Plan do 38"-) e culmina xustamente en 1970 coa Lei Xeral de Educación á que nos referimos, xa máis fóra que dentro do franquismo...

As dúas leis, que se sitúan ó principio e ó final da Ditadura, van afectar fondamente a todo o entramado educativo español e a Galicia en particular. Curiosamente -e paradoxalmente - son ámbalas dúas as disposicións legais que deron lugar á máis fonda 
renovación educativa do franquismo, e, desde logo, as dúas leis educativas de maior éxito, as que chegaron máis lonxe, as que removeron a estrutura social española ata o fondo.

A primeira, de 1938, foi a que propiciou a formación de tódolos cadros medios do país ata 1959. ¿Que pretendía con aquela lei o réxime de Franco? O obxectivo era claro: tratábase de crear a infraestrutura educativa necesaria para formar ideolóxica, cultural e politicamente, os cadros dirixentes que ía necesitar o réxime para implantarse socialmente. É dicir, tratábase de "captar" —ou "capturar" máis ben— as clases medias. O réxime buscaba o seu apoio social "natural"... Con este fin, deseñaron un bacharelato de sete anos que ensanchaba enormemente a secundaria, que arrincaba as futuras elites (era un plan claramente elitista) da escola primaria antes de tempo, para pasalas ós institutos de ensino medio (e, sobre todo, ós colexios privados relixiosos), que abandonaba á súa sorte a primaria (como castigo ás clases populares - fieis á República- e como primeiro paso para o desmantelamento do sistema educativo republicano) e que preparaba o terreo para a reorganización dos estudos universitarios.

Este novo bacharelato supoñía unha hábil manobra política do réxime de Franco, que tería moito éxito social. En realidade, foi, durante moitos anos, a plataforma máis sólida para a formación de cadros medios e, sen discusión, a gran baza pedagóxica do réxime ata os anos sesenta. Era o equivalente do que hoxe pode ser un diplomado universitario; posuía un gran valor en si mesmo; era un medio, pero tamén un fin. O seu contido ideolóxico era claro, con relixión, latín e matemáticas en tódolos cursos. É dicir, era un típico bacharelato de corte "napoleónico", pensado —como dicimos_ para a captación das clases medias. Nel coincidían as "ciencias", as "letras" e a ideoloxía política "necesaria", desde 0 nacional-sindicalismo ó nacional-catolicismo. Nunha palabra, foi un auténtico golpe de inspiración para os obxectivos do réxime. Nos anos sesenta, o dobre bacharelato (elemental e superior) tecnificaría moito máis os estudos medios, que pasarían a ter un carácter máis propedéutico, máis preuniversitario.

E se así foi coa Lei do 38, coa segunda das grandes leis educativas do franquismo, a Lei Xeral de 1970, pasaría outro tanto, pero con consecuencias distintas que foron quizais aínda máis lonxe... A "Ley Villar" daría lugar a grandes discusións no interior mesmo do "sistema" e levantaría ronchas entre os distintos sectores sociais, políticos e económicos do réxime. E cumpriría engadir axiña que a oposición política democrática daquel tempo nunca soubo calibrar moi ben o calado verdadeiro da Lei, que ía moito máis alá do que se pensaba.

Convén rememorar todo isto para entender a situación actual do sistema educativo en Galicia. Como ben di Pierre Vilar, a historia trata de "comprender o pasado para mellor coñecer o presente e, dalgún xeito, anticipar o futuro". No fondo, a historia é unha ciencia do futuro, máis que do pasado. Caricaturizando a situación, case poderíamos dicir, pois, que canto mellor "comprendamos" a LXE, de 1970, mellor "coñeceremos" a LOGSE, de 1990. Ou, canto máis saibamos de Rousseau, mellor entenderemos ó Ministro de Educación de turno. E, por suposto, canto máis a fondo "entremos" en Xoán Vicente Viqueira, máis críticos seremos co Conselleiro de Educación... A verdadeira historia non consiste en recrearse no pasado senón en revirarse momentaneamente e mirar atrás, para saber cara onde 
tirar despois. Indagamos para orientarnos. As pesquisas teñen sempre unha intención de futuro. $\mathrm{O}$ que verdadeiramente nos desacouga é o porvir. O pasado vivo — porque tamén hai un pasado morto - serve só para explicar, para interpretar, para aclarar. Por iso é bo que non teñamos que lamentarnos diante do que xa está inevitablemente consumado...

Así pois, a partir de 1968 danse tódalas condicións para proceder a unha reestruturación total do sistema educativo español. Os anos sesenta supuxeran un crecemento económico considerable; a saída de emigrantes a Europa e a entrada de España no gran desenvolvemento capitalista europeo deixaba o país xa maduro para acometer unha reforma profunda da educación, buscando, xustamente, a mellor adecuación entre o seu sistema produtivo e o sistema educativo.

A experiencia republicana - tan fonda, tan rica, tan curta - ficaba lonxe xa. A lembranza e a señardade eran sentimentos inmarcesibles de 1931 ou 1936. "Nunca habíamos estado tan contentos juntos, porque nunca estuvimos contentos y muy pocas veces, juntos", diría María Zambrano falando da España republicana. "España ha muerto", escribiría María Teresa León rememorando a Luis Cernuda e o sentimento de tantas e tantos combatentes republicanos, despois da amarguísima derrota na guerra civil. Idea esta sobre a que retorna unha e outra vez María Teresa en Memoria de la melancolía, insistindo no apoio das nacionalidades históricas á República. Por iso Manuel Azaña puido gritar un día en Barcelona "iViva España!"; por iso o PNV apostou pola República ata o final; e por iso Galicia aprobou maioritariamente o Estatuto. ¡Tempos aqueles en que todo era sumar!, como tamén dicía María Zambrano...

Con Franco, todo iría a peor. A actitude fascista de forzar unha unidade artificial de España, tivo exactamente o efecto contrario: rompeuna por dentro. E xa nunca máis se puido recompoñer. Falar hoxe desa España, da idea franquista de España —en Euskalherría, en Cataluña ou en Galicia- é buscar sentimentos tronzados hai tempo, sentimentos imposibles para unha boa parte deses pobos e que hoxe son a herdanza da dereita máis cerrada. Foi o franquismo o que nos legou unha "cuestión nacional" envelenada polo odio e o resentimento. A remodelación do Estado é hoxe unha necesidade apremiante para restañar dunha vez as vellas feridas...

Por tanto, a LXE, de 1970, supón unha reformulación radical do sistema educativo español. Tan completa é que non sería esaxerado cualificala de auténtica ruptura pedagóxica. Nunha ollada de conxunto ós últimos setenta anos da historia de España, non é desatinado situar en 1931 - coa proclamación da II República - a caída do "antigo réxime" ou "réxime de servidume" (polo menos, na conciencia social das xentes). A partir daquel momento, nada podía ser igual ca antes. E nada foi, efectivamente, igual ca antes. Nin sequera durante os corenta anos de ditadura franquista. A República tivo o mesmo efecto sobre as conciencias que a Revolución de 1789 en Francia ou a de 1848 no resto de Europa.

Unha persoa tan pouco sospeitosa hoxe de esquerdismo como Ramón Tamames, sitúa a verdadeira ruptura política -expresión, por certo, abondosamente empregada nos últimos anos setenta - da España do noso tempo, é dicir, a creba do vello Estado, xusta- 
mente nese ano. Iso é o que di no seu xa vello libro La República. La era de Franco. E, nesa mesma obra, sitúa igualmente a ruptura económica -inicio da modernización material de España - en 1959. Idea por certo que non comparten Nicolás Sartorius nin Javier Alfaya no seu libro La memoria insumisa, no que, ademais de desenvolver un durísimo alegato contra a ditadura franquista desde tódolos puntos de vista, sosteñen que a modernización económica e material de España data tamén da época da República, sendo o franquismo unha época histórica reaccionaria e criminal da que non salvan absolutamente nada. De tódolos xeitos, seguindo agora o razoamento de Tamames, non sería - coido- ningún disparate situar a ruptura pedagóxica en 1970.

Non é cousa agora de entrarmos en disquisicións sobre o fondo da "Ley". Xa existen estudos meritorios sobre a mesma. Noustante, cómpre salientar o magnífico ensaio - sempre tan lucidamente crítico e tan analítico- de Carlos Lerena "Acerca de las funciones ideológicas del sistema de enseñanza tecnocrático en la España de los setenta", que, como se sabe, aparece incluído na segunda edición da súa obra Escuela, ideología y clases sociales en España, de 1986.

O certo é que España -e Galicia con ela - non tiña unha lei de educación dende a case "prehistórica" Lei Moyano (1857). Lei aquela puramente "administrativista" —por iso serviu tanto tempo-. De facto, a celeridade das reformas republicanas sobordou con moito os marcos legais, aínda que nin sequera tivo tempo nin acougo para promulgar unha lei de educación que tanto se necesitaba. Lorenzo Luzuriaga, o pedagogo institucionista e socialista máis dedicado ás tarefas prácticas en materia de política educativa, publicou unha pequena monografía que levaba este título tan explícito: Ideas para una reforma constitucional de la educación pública, que, como se ve, vén sendo un auténtico borrador de "lei de educación". Como di Pierre Vilar, a República plantexou tódolos problemas, pero non puido resolver perdurablemente ningún. A encrucillada internacional non podía ser peor, pero ninguén era quen de negar o carácter verdadeiramente auroral daqueles anos inmortais ("un sentir, unha memoria, un futuro"...).

Pola súa banda, o franquismo, ata que se sentiu economicamente consolidado, xa na década dos sesenta (e malia a súa obxectiva precariedade política), non se propuxo tampouco unha lei desa envergadura. Ata que, por fin, en 1970, tódalas expectativas dos profesionais da educación e da enteira poboación escolar parecían cumprirse. Pero, visto máis de preto, a cousa xa non está tan clara. Había contradicións entre distintos sectores do "sistema" político. Axiña chegaría a crise do petróleo -1973-. Xurdiron rapidamente problemas de financiación. Moi pronto, o que empezou sendo a "reforma Villar Palasí" ía converterse na "contrarreforma Martínez Esteruelas" —o ministro seguinte-. O financiamento foi a talón de Aquiles da reforma. ¡Curioso! Parece un sino. Os problemas da LOGSE, vinte anos despois (1990), ían ser os mesmos — crise económica de 1992—.

\section{Galicia hoxe}

Hoxe (11 de febreiro do ano 2000), en que isto escribo, puiden ler, na primeira páxina do diario $O$ Correo Galego, este titular: "Galicia está entre as tres rexións europeas máis 
optimistas para 0 ano 2000"... ¡Que alegría! ¡Está a cambiar aceleradamente 0 carácter do noso pobo! —pensei- ¿Será posible que, en aberta caída demográfica e en plena crise socioeconómica estrutural, os galegos se sintan tan optimistas? É certo, si, que todo depende dos indicadores económicos que se consulten. É verdade tamén que existe innovación e creatividade en varios sectores da produción. Hai logros evidentes nalgunhas reconversións... Pero tampouco parece que sexa como para tirar foguetes. Pronto saín de dúbidas: o titular en cuestión referíase a unha enquisa levada a cabo entre empresarios. ¡Son eles os optimistas! Parece que se trata de ir "facendo ambiente" con vistas ó inicio da campaña electoral, que se anuncia quente e intensa...

Os cambios políticos de 1996, cunha recuperación substancial das magnitudes macroeconómicas, deron lugar igualmente a certas modificacións macroeducativas. En plena euforia internacional da "globalización neoliberal", todo se foi reducindo a un retorno involutivo camiño da privatización. ¿Será posible desandar o camiño mal andado? ¿Será posible superar algún día e dunha vez por todas o vello dilema escola pública/escola privada? Porque se chegamos á conclusión de que a educación é cousa de todos, acábase o problema. Poderemos aceptar tódalas innovacións, experiencias e aportacións privadas que se queira, pero o básico e o fundamental (unha escola plural, si, pero pública e laica) debe estar cuberto polo que é de todos, isto é, polos presupostos xerais do Estado. E Galicia debería entrar no novo milenio con competencias soberanas en materia de educación.

Temos que avanzar no camiño da "normalización" do noso país, tal e como apuntaba, hai xa máis de dez anos, Xosé Manuel Beiras, no seu libro de conversas con FernánVello e Pillado Mayor A nación incesante. Beiras — que naceu co Frente Popular, como el di- afirmaba: "coido que existe xa unha avenza de reflexión, de pensamento e de cristalización en coordenadas de teoría política (...), como alicerces do nacionalismo, e non xa na actualidade, senón desde hai certo tempo; concretamente, desde a fase histórica do nacionalismo na Segunda República Española, nos anos 30". ¡Outra vez a República como forma de Estado incesante!...

Habería que perfilar un modelo de Educación para o modelo de Estado que queremos (¿camiñamos inexorablemente cara a un modelo de Estado federal?). Modelo de educación que debería partir, en calquera caso, como acabamos de dicir, dunha escola plural, pública e laica -insisto-. Plural, porque a realidade galega é xa —e serao cada día máis- unha realidade social e culturalmente diversa. A demografía vai impor a súa lei. A mestizaxe será pronto unha nova realidade. Pero a conciencia da identidade nacional seguirá a pesar, namentres pesen a lingua, a cultura e o novo tipo de educación que se necesita. Os componentes sensibles e emocionais - como di Beiras- seguirán tendo un papel importante, aínda que se desenvolva a fondo o "movemento político organizado" e o que poderíamos chamar "corpus teórico nacionalista".

Escola pública, isto é, educación común e de todos, fronte ós estreitos intereses privados e minoritarios. Non se trata de excluír, senón de incluír ós exclusores. Escola laica, ou o que é o mesmo, o contrario da escola confesional, privada e particular. Unha reivindicación tan vella como as revolucións burguesas contemporáneas. A consecuencia natural da separación Igrexa/Estado. 
Neste ano do seu centenario -e nunca en mellor sitio ca este, tan vencellado desde o inicio ó seu nome - vén a conto, a propósito dos nosos sentimentos e da situación do mundo en que nos tocou vivir, unha fermosa cita de Castelao en Sempre en Galiza: "Por qué no desterro a verba 'patria' é, para nós, máis emotiva que a verba 'nación'? ¿Será que a patria emerxe do puro sentimento e a nación non pasa de ser unha realidade obxetiva? Dende logo, a patria sentímola dentro de nós mesmos e acompáñanos no desterro; pero a nación está na terra lonxana, nas rexións do recordo e a espranza. A nación é o obxeto amado; a patria é o amor que a nación nos infunde. De tal modo, que sen a concencia nacional non se comprende o sentimento patriótico".

Velaí un exemplo de conceptualización política a partires do sentimento máis depurado. Cita definidora e pletórica de lirismo e de poder evocador. Amor e precisión. Lonxe, moi lonxe da frialdade socioloxista con que hoxe se analiza, ás veces, a cuestión nacional, como simple reacción identitaria fronte ás distintas formas de globalización. 0 sentimento e a conciencia nacional debe ser algo máis ca un refuxio, tal e como apunta Manuel Castells no seu libro La era de la información.

No seu vasto estudo sociolóxico -e no volume $I^{\circ}$, titulado xustamente El poder de la identidad-, M. Castells, dentro dun capítulo que reza Paraísos comunales: identidad y sentido en la sociedad red, afirma: "La identidad es la fuente de sentido y experiencia para la gente". E engade — citando a Calhoun-: "No conocemos gente sin nombre, ni lenguas o culturas en las que no se establezcan de alguna manera distinciones entre yo y el otro, nosotros y ellos". E segue: "Por identidad, en lo referente a los actores sociales, entiendo el proceso de construcción del sentido atendiendo a un atributo cultural". Despois dunha análise moi polo miúdo do papel xogado polas nacións que a compoñían na desintegración da Unión Soviética, aborda o tema das nacións sen Estado, exemplificado en Catalunya. Un pouco máis adiante, no epígrafe "Las naciones de la era de la información", afirma: "Nuestra digresión sobre los dos extremos opuestos de Europa aporta algún conocimiento sobre la nueva función de las naciones y el nacionalismo como fuente de significado en la era de la información". A partir daí, e xa no ámbito do máis discutible, entra a fondo nada menos que nun intento de redefinición do concepto de nación, que poida ser de utilidade no mundo da 'era da información'...

Imposible, pois, en calquera caso, separar o sentimento nacional, a conciencia nacional, a idea de patria - que tan fermosamente definía Castelao en Sempre en Galiza, en momentos especialmente amargos para a patria e para el mesmo- das características que deben ter os distintos instrumentos políticos -e por suposto o sistema educativo, aínda que non sexa propio (problema sempre difícil, delicado e de recuperación política reivindicativa permanente, nas nacións sen Estado).

Un pouco máis abaixo -e no epígrafe citado antes- Castells insiste: "Los atributos que refuerzan la identidad nacional... varían, aunque, en todos los casos, presuponen una historia compartida a lo largo del tiempo. Sin embargo, plantearía la hipótesis de que la lengua, sobre todo una plenamente desarrollada, es un atributo fundamental de autorreconocimiento y para el establecimiento de una frontera nacional invisible menos arbitraria 
que la territorialidad y menos exclusiva que la etnicidad. Ello se debe, en una perspectiva histórica, a que proporciona el vínculo entre la esfera pública y la esfera privada, y entre el pasado y el presente, prescindiendo del reconocimiento real de una comunidad cultural por parte de las instituciones del estado (...) Si el nacionalismo es frecuentemente una reacción contra una identidad autónoma amenazada, en un mundo sometido a la homogeneización cultural por la ideología de la modernización y el poder de los medios de comunicación globales, la lengua, como expresión directa de la cultura, se convierte en la trinchera de la resistencia cultural, el último bastión del autocontrol, el refugio del significado identificable". Cita longa, pero ben explicativa de algo que nos afecta...

A cuestión da lingua foi un dos camiños para a recuperación da nación galega despois da guerra civil. A lingua e a cultura sostiveron a loita nos días da represión e da "Ionga noite de pedra" - tan emotivamente cantada por Celso Emilio Ferreiro-. Ano este do 2000, de fronteiras, "misterios", "cataclismos", pero tamén de conmemoracións. A lingua e a cultura, a economía e as comunicacións e, como non, os intercambios educativos —cada día máis intensos - poden axudarnos a "borrar" as fronteiras co Portugal irmán, para construír un auténtico "eixo atlántico", un novo mundo no occidente de lberia. Por iso convén avanzar nos mínimos da lingua e nos máximos da cultura. Por iso convén confraternizar...

Cen anos de Castelao — diciamos antes-. Pero tamén (a polémica case sempre está servida...), cincuenta anos de Galaxia. Xosé Manuel Beiras, en A nación incesante, falando de si propio, dirá: "O meu contacto establece-se sobre todo a partir xa do intre en que entro na universidade, un contacto constante, no senso en que o grupo de Galaxia operaba e funcionaba levando a formación destas novas xeracións e tentando levá-las cara o rego dunha estratéxia política". E, un pouco máis adiante, explicando a súa colaboración con Galaxia, dirá o Beiras: "Nós comezamos a ter unha participación activa, insisto, aínda sendo estudantes, através de traballos que se nos encomendan. É cando Xaime Isla Couto acorda promover e financiar el mesmo unha colección dentro da Editorial Galaxia, que vai ser onde se van expresar 'os novos', onde se vai publicar a produción dos novos (...) Outra cousa é xa a miña colaboración posterior con Galaxia nos anos sesenta, cando eu me encarrego da Revista de Economía de Galicia", remata Beiras.

Pouco a pouco, irán aparecendo, ó longo diste ano, os traballos conmemorativos e, como apuntabamos máis arriba, as distintas perspectivas críticas. En Galaxia aparecería por exemplo, en 1969, unha das primeiras publicacións en galego en materia de educación: Educación e desenrolo, de Xesús Cambre Mariño. A revista Grial segue a ser aínda hoxe -e, ultimamente, dunha maneira máis decidida — o referente histórico da editorial.

\section{Cara a un novo sistema}

Un país, unha fala, un sistema educativo. ¿Cal debería ser o deseño dunha escola galega no eixo do terceiro milenio? Temos que insistir: unha escola gratuíta, obrigatoria, pública, laica e plural. No "antigo réxime", a educación era un privilexio. Ó alborear a época contemporánea, pasou a ser un servizo. A partires da Revolución Francesa de 1789, foi reivindicada, polos países máis avanzados, como un dereito. 
A escasa cultura política democrática dos pobos de España, na súa historia máis recente, déixase sentir nesa falta de "conciencia nacional" á hora de defender eses dereitos, sobre todo, o dereito á educación -e en Galicia, dun xeito particular-. Mentres os franceses defenden a súa escola pública, republicana e laica en todo momento e en todo lugar, como unha auténtica riqueza nacional —como os árabes defenden o petróleo, por exemplo-, aquí non temos para nada a convicción de que a mellor maneira de avanzar sexa investindo en educación. Sábese por experiencia que é máis difícil saír do subdesenvolvemento cultural que do subdesenvolvemento material. Porque coa educación pasa como coa liberdade: só se bota en falta cando non se ten. Ser cultos para ser libres, dicía José Martí. A educación é o poder máis grande. Máis que o poder económico e máis que 0 poder político... A educación é o poder da verdade e o achegamento máximo ás respostas das preguntas últimas.

Escola gratuíta para facela extensiva ó conxunto da poboación, dende idades moi temperás ata máis alá da adolescencia. Escola gratuíta para poder facela verdadeiramente obrigatoria e, polo tanto, universal. Vella, vellísima reivindicación política revolucionaria, que sempre quixo facer da educación unha panca de transformación social. Reclamación da pedagoxía reformadora máis clásica e máis sentidamente social. Pero, non o esquezamos, o que nalgún tempo parecía pensamento utópico —simple "utopismo pedagóxico"-, no mundo de hoxe convértese en pura necesidade económica ("capital humano", en expresión non moi afortunada dos teóricos), ideolóxica e cultural. Ou, como diría Louis Althusser, "práctica técnica" — saber, aprendizaxe, técnica, ciencia- e "práctica social" - ideoloxía, sistema, aparato ideolóxico de Estado-.

Escola obrigatoria, como xa o viña sendo, sobre o papel, en Europa, desde os tempos Ionxanos do Informe Condorcet (en 1792, en pleno proceso revolucionario francés) e, lexislativamente, a partires da promulgación das "Leis Férry" (1881), sobre gratuidade, obrigatoriedade e laicidade escolar, que marcaron un fito na configuración dos sistemas educativos europeos.

En realidade, se, tal e como diciamos ó principio, as orixes teóricas da educación pública están na Atenas clásica dos séculos V e IV antes da nosa era, as orixes institucionais atópanse nas prácticas escolares medievais, como moi ben sinala Emile Durkheim na súa obra Historia de la educación y de las doctrinas pedagógicas. É entón cando a educación se converte en sistema, aínda que non se trate precisamente dun sistema ó servizo do Estado, senón ó servizo da superestrutura política dominante na Idade Media: a Igrexa.

Pola súa parte, e a partires de 1730 aproximadamente, o movemento da llustración construirá a teoría textual do que será a educación pública contemporánea nas sociedades capitalistas. Pouco despois, os Cahiers de doléances, os populares Cadernos de queixas, elaborados polos representantes populares reunidos en Versalles, en vésperas da Revolución (maio de 1789), converteranse na expresión máis esgazadora das necesidades populares, que xa viñan de seren apuntadas polos ilustrados. Pensemos, por exemplo, nas páxinas maxistrais de Rousseau, encol da educación pública, no seu Discurso sobre a economía política, no capítulo primeiro do Emilio ou na pequena obriña Consideracións 
sobre o goberno de Polonia. Nelas, Rousseau, inspirándose nos clásicos, senta as bases para a configuración dos sistemas educativos a partir da construción nacional. Hoxe, en cambio, a Unión Europea, supón certas cesións de soberanía a cambio dunha mellor defensa dos intereses comúns. De todas formas, convén non perder de vista que unha cousa é a Europa do capital e outra ben distinta a Europa do traballo, a Europa das clases populares. Naturalmente, Rousseau estaba a traballar daquela —-mesmo sen sabelo— para as burguesías nacionais de Europa.

Outro tanto cabería dicir de Diderot. Na súa obra de encargo Plan dunha Universidade para o goberno de Rusia, o director da Enciclopedia e gran animador e organizador dos círculos ilustrados, expón as súas teorías sobre as relacións entre política e educación e sobre o papel especialmente delicado da educación en tanto que xeradora da mellor atmósfera social para o bo funcionamento das leis. A educación é a auténtica gardiá das leis e dos bos costumes, e non a relixión, como pensaba Voltaire. A educación, cohesiona. A educación suaviza as tensións. A educación é un bálsamo social. Como se ve, Diderot repara, neste caso, na función meramente reprodutora da educación. Pero sabía -e sabía ben-que a educación tamén é produtora de cultura e fonte permanente de crítica.

Pola súa banda, e para completar a tríada que pode exemplificar mellor este salto cualitativo da educación como aparato de Estado, Helvétius - un materialista ilustrado coas ideas moi claras - chega á conclusión de que a educación debe figurar "na constitución mesma dos Estados". Isto é, plantea, pola primeira vez, na súa obra De l'Esprit, que a educación debería ser un dereito constitucional. Lección que, como xa vimos, aprenderá moi ben Lorenzo Luzuriaga, no proceso republicano español, tal e como se ve no título mesmo do seu opúsculo Ideas para una reforma constitucional de la educación pública.

Por último, e en particular entre 1789 e 1794, os Rapports, os célebres Informes sobre educación do proceso revolucionario francés que marca o cambio de século —do XVIII para o XIX-, virán a ser a síntese práctica máis rechamante que recolle esa teoría textual ilustrada á que nos referimos e esas necesidades populares que aparecen tan apremiantemente formuladas nos Cahiers. Non importa que os Rapports caian ás veces nas utopías máis desaforadas. Historicamente, importa moito máis o transfondo que reflicten que 0 que realmente din. Non sempre interesa a mensaxe explícita, senón o contido latente, a actitude, o espírito. E está claro que, cos Rapports -e, sobre todo, co máis completo e máis famoso de todos eles: o Informe sobre a organización xeral da instrución pública, de Condorcet-, a educación conságrase como un aparato de Estado de primeira orde, como un poder auténtico, que dirá Talleyrand. A educación xa empezaba a ser daquela un medio insubstituíble de reprodución das estruturas dos Estados contemporáneos. Aínda que non deberiamos esquecer que, ademais da súa capacidade reprodutora, a educación pode tamén producir cultura e está en posesión dun considerable potencial transformador e crítico, como acabamos de dicir.

Escola pública, por tanto. A escola como un especialísimo asunto público. Unha escola — pública - que se foi reducindo perigosamente nos seus horizontes e se foi facendo cada vez máis primaria, máis profesional e máis de pobres, como diría —no século XIX—o pe- 
dagogo suízo Juan Enrique Pestalozzi, tan no centro do que hoxe se chama a "educación social". Así se foron configurando historicamente as dúas redes de escolaridade das que falaron hai tempo os sociólogos franceses Baudelot e Establet: a PP (Primaria/Profesional) e a SS (Secundaria/Superior). Pirámide escolar que eles deseñan na súa obra La escuela capitalista en Francia e na que aparecen os escolares que non pasarán da primaria e da profesional e os que poderán escalar ata o cumio da pirámide na secundaria e na superior. É dicir, a escola foise dividindo máis e máis. Canto máis única a pretendían os pedagogos, máis dividida estaba. E, paralelamente, o sistema educativo, no seu conxunto, foise escindindo tamén máis e máis. 0 transvase de alumnos da PP á SS era practicamente inexistente.

Escola laica e plural. Unha escola que recolla a necesaria separación dos poderes públicos e os poderes eclesiásticos e que impoña dunha vez por todas o carácter civil do ensino. Xa o dixera Condorcet: a relixión, nas igrexas; na escola, a moral civil. Así pois, escola laica fronte a escola confesional. E unha escola que recolla tódolos elementos positivos do proceso histórico contemporáneo, ensanchando os horizontes da vella escola única republicana, incapaz hoxe de abranguer unha realidade tan complexa como a nosa. Ó mesmo tempo, unha escola activa, é dicir, unha escola non pasiva, unha escola metodoloxicamente innovadora e creativa; nunha palabra, unha escola inconformista.

\section{4. ¿Que futuro?}

O sistema educativo estatal español atópase, neste cambio de época, nunha encrucillada. En realidade, é todo o sistema social, no seu conxunto, o que está en crise. Porque a situación mundial mesma é unha situación crítica. Como di Manuel Castells, en La era de la información: "Los cambios sociales son tan espectaculares como los procesos de transformación tecnológicos y económicos (...) En buena parte del mundo, las relaciones de género se han convertido en un dominio contestado, en vez de ser una esfera de reproducción cultural. De ahí se deduce una redefinición fundamental de las relaciones entre mujeres, hombres y niños y, de este modo, de la familia, la sexualidad y la personalidad. La conciencia medioambiental ha calado las instituciones de la sociedad y sus valores han ganado atractivo político al precio de ser falseados y manipulados en la práctica cotidiana de las grandes empresas y las burocracias. Los sistemas políticos están sumidos en una crisis estructural de legitimidad (...) Los movimientos sociales tienden a ser fragmentados, localistas, orientados a un único tema y efímeros (...) En un mundo de flujos globales de riqueza, poder e imágenes, la búsqueda de la identidad... se convierte en la fuente fundamental de significado social (...) Es cada vez más habitual que la gente no organice su significado en torno a lo que hace, sino por lo que es o cree ser" —afirma-.

$\mathrm{Na}$ "presentación" do seu libro — que vimos citando — La red y el yo, Castells segue dicindo: "...Mientras que, por otra parte, las redes globales de intercambios instrumentales conectan o desconectan de forma selectiva individuos, grupos, regiones o incluso países según su importancia para cumplir las metas procesadas en la red, en una corriente incesante de decisiones estratégicas. De ello se sigue una división fundamental entre el ins- 
trumentalismo abstracto y universal, y las identidades particularistas de raíces históricas". E conclúe: "Nuestras sociedades se estructuran cada vez más en torno a una posición bipolar entre la red y el yo".

Pola súa banda, a coñecida socióloga chilena Marta Harnecker —que pasou non hai moito por estas Aulas-, no seu último libro La izquierda en el umbral del siglo XXI. Haciendo posible lo imposible, que vén de aparecer, faise cargo igualmente da situación de cambio revolucionario -nesta última fase da revolución científico-técnica, que está a pasar-e trata de deseñar unha estratexia, desde posicións ideolóxico-políticas netamente de esquerdas, en América Latina. Á hora de definir a nova terminoloxía, tan abondosamente empregada, fala de globalización como un novo concepto en economía, de neoliberalismo como concepto último no dominio da política e de pensamento único como a ideoloxía dominante neste cambio de milenio.

Nun estudo titulado Déficits del sistema educativo, que aparece no libro colectivo Educación y sociedad de la información —-publicado polo ICE da Universidade de Santiago, en 1999-, José Manuel Touriñán López correlaciona os valores educativos con tres acontecementos: a sociedade da información, a mundialización e a civilización científico-técnica. E considera que, nesta sociedade global, a educación, a investigación, o desenvolvemento tecnolóxico, a innovación e as redes de información e comunicación xogan un papel especialmente significativo. Parte igualmente do suposto de que teñen afinidade entre si as que el chama distintas globalizacións -económica, política, cultural e socioeducativa一, que nunca serán explicables unhas polas outras, senón cada unha por si mesma e todas, en mutua interdependencia —afirma-.

Visto isto, parece claro que o sistema educativo galego do futuro deberá ser cada vez máis ancho e máis longo. Abranguerá tramos longos de idade e comprenderá sectores cada vez máis anchos da sociedade en novas tarefas de educación de adultos, educación permanente e formación continua. Son cada día máis abundantes as aportacións de todo tipo nestes campos do saber pedagóxico. 0 que para Condorcet era unha esixencia das "luces" - alfabetizar adultos para crear riqueza cultural e material na sociedade- é hoxe unha necesidade apremiante como consecuencia da celeridade da revolución tecnolóxica. Teremos que educarnos e formarnos continua e permanentemente durante toda a vida. A paideia platónica, o curriculum na Academia en Atenas, dicíase que duraba ata os cincuenta anos... Hoxe, non ten límites.

Pero en educación, naturalmente, tamén hai que normalizar país. Debemos ser máis nós que nunca, pero é preciso estar máis que nunca en Europa e no mundo. "Globalización" e "nación-identidade" necesítanse mutuamente. Deberemos prepararnos para domeñar e dominar o que parece inevitable. $E$ todo iso, só poderemos conseguilo tendo sempre presente ese concepto de historia como proceso ó que me refería máis arriba. Marta Harnecker, no libro antes citado, identifícase coa afirmación althusseriana de que o gran aporte de Marx foi xustamente o de ter fundado a ciencia da historia, "uno de los más grandes acontecimientos de la historia del conocimiento humano" —di-. Para Louis Althusser —afirma M. Harnecker - Marx sería o descubridor dun novo continente científi- 
co, "de la misma manera que, con anterioridad, Tales había fundado el de las Matemáticas y Galileo el de la Física".

Como é sabido, corren tempos difíciles para unha axeitada inserción do sistema educativo na estrutura do Estado. Porque o propio Estado español necesita urxentemente unha remodelación. Remodelación que, en todo caso, pasa necesariamente polo camiño que leva ó noso dereito de autodeterminación. E desa remodelación - do seu alcance e das súas características- dependerán os cambios no propio sistema educativo ou nos distintos sistemas educativos dese Estado ¿federal? De calquera xeito, a entrada en Europa está a condicionar globalmente a nosa situación como país, incluída, loxicamente, a educación.

Hoxe mesmo, xa, a situación de conxunto en tódolos pobos de España — cos desaxustes que se queira, é verdade, e con tódalas diferencias históricas de desenvolvementopermite albiscar unha reestruturación profunda do sistema educativo. A crise curricular e de organización do profesorado ou os cambios en materia de política educativa propiciados pola LOGSE, a partir de 1990, están a crear, obxectivamente, unha nova realidade escolar. E están a provocar - tamén é verdade - situacións de tensión e desconcerto nos distintos sectores do ensino, que deberán seren corrixidos rapidamente.

Preséntese a necesidade dun "alongamento", na escola gratuíta e obrigatoria, ó principio e ó final. A escolaridade deberá abranguer —á volta de moi pouco tempo-dende os 3 ata os 18 anos, ensanchando o curriculum por abaixo e por arriba. Todo iso debería facerse nun só ciclo de ensino, sen solución de continuidade entre a primaria e a secundaria, que desaparecerían como tales. Habería un só tipo de centros de formación e un profesorado especializado nos distintos tramos de idade. Unha boa planificación e un só tipo de formación do profesorado, con distintas especializacións, facilitarían ese novo tipo de educación que inevitablemente se ía desenvolver. Todo apunta a iso, se o que se pretende é unha mellora substancial nesa nova educación — plural, intercultural— que está a piques de nacer.

$E$ aínda que todo isto soe forte, non se trata de ningunha revolución. Xa a finais do século XIX, os homes da Institución Libre de Enseñanza, en Madrid, puxeran en práctica un ciclo único que tiña exactamente esa acoutación: dos 3 ós 18 anos. Naturalmente, eran pioneiros e avanzados da renovación pedagóxica daquel tempo. Eran auténticos revolucionarios e innovadores na metodoloxía didáctica. Por iso, o que eles fixeron entón sérvenos hoxe a nós. E moi a propósito por certo.

Polo que respecta á Universidade, resultan evidentes as transformacións destes últimos anos. Pero non interesa agora se esa institución responde ou non ás esixencias da época. Queremos coñecer máis ben a súa nova función social. No século XIX, en Europa, contábase cunha universidade en cada rexión, cun liceo, ximnasio ou instituto —-segundo 0 país que tomemos como referencia- en cada capital de provincia ou departamento e cunha escola en cada lugar, vila ou aldea. Hoxe, cen anos despois, contamos cun complexo escolar, unha graduada, un colexio nacional —ou chámase como se queira — en cada vila. E en cada vila tamén un instituto. Duplicación de servizos educativos que convén unificar 
(por iso diciamos máis arriba ciclo único e unificación de primaria e secundaria). E, en cada capital de provincia ou cidade importante, unha Universidade. Isto é, as tarefas de socialización que antes desempeñaban os establecementos de secundaria, son desenvolvidas agora pola propia educación superior, que pasa a ser así un nivel do sistema educativo con novas funcións docentes e sociais, ademais da súa actividade investigadora e cultural, máis alá, por tanto, do que, por exemplo, planteaba Ortega y Gasset na súa célebre obra Misión de la Universidad.

Seguramente, a cualificación, preparación e formación profesional terá lugar, ademais de na propia Universidade, noutras instancias máis específicas. A educación técnica foi sempre, historicamente, un dominio moi cambiante, en flutuación continua, e en función, como é natural, do progreso material e técnico e do proceso de división social do traballo.

Para ilustrar esta situación, abóndanos con botarlle unha ollada ó panorama universitario galego de agora mesmo: Santiago de Compostela, Lugo, Vigo, Ourense, Pontevedra, Coruña, Ferrol... Cidades todas que teñen algo que dicir no que se refire á educación universitaria. De momento, non hai outro futuro...

Por conseguinte, en todo o que se relaciona co porvir do noso país, tanto desde o punto de vista social, como económico, político, lingüístico, cultural ou educativo, só podemos dicir, recordando ós filósofos da modernidade: jtemos o deber cívico e moral de ser felices e optimistas! E, con Uxío Novoneyra, dende o corazón de Os Eidos, dicir agora, pensando en Galicia e nos galegos: "sabemos que ti podes ser outra cousa / sabemos que o home pode ser outra cousa".

(Publicado en Aula Castelao de Filosofia (comp.), Globalización e cambio de milenio, Vigo, Edicións Xerais de Galicia, 2001, páxs. 201-217.) 